\title{
Erratum to: Giant extragenital Bowen's disease
}

\author{
Ilko Bakardzhiev · Anastasiya Atanasova Chokoeva · Georgi Tchernev
}

Published online: 30 November 2015

(C) Springer-Verlag Wien 2015

\section{Erratum to: Wien Med Wochenschr DOI 10.1007/s10354-015-0396-Z}

We would like to correct the name of a colleague, which has participated in a paper recently published in WMW: Giant extragenital Bowen's disease. Bakardzhiev I, Atana- sova Chokoeva A, Tchernev G. Wien Med Wochenschr. 2015 Nov 5. [Epub ahead of print]. The correct abbreviation for the name of Dr. Chokoeva for medline indexation has to be the following one: Chokoeva A. A.

The online version of the original article can be found under doi:10.1007/s10354-015-0396-z

Assoc. Prof. G. Tchernev $(\bowtie)$

Medical Faculty,University Hospital Lozenetz,

Koziak street 1,

1407 Sofia, Bulgaria

e-mail: georgi_tchernev@yahoo.de

Assoc. Prof. I. Bakardzhiev

Medical College, Medical University of Varna,

84 Tzar Osvoboditel str.,

9000 Varna, Bulgaria

e-mail:varna2008@gmail.com

Dr. A. A. Chokoeva

"Onkoderma" -Policlinic for Dermatology and Dermatologic,

Surgery,

General Skobelev 26 blvd.,

Sofia, Bulgaria

e-mail: assia_chokoeva@abv.bg

Assoc. Prof. G. Tchernev

Policlinic for Dermatology and Venereology, Saint Kliment,

Ohridski University,

Sofia, Bulgaria 